\title{
Technological Pedagogical Content Knowledge of Mathematics Teachers and the Effect of Demographic Variables
}

\author{
Melike Ozudogru \\ Manisa Celal Bayar University, Turkey \\ Fatma Ozudogru \\ Usak University, Turkey
}

Submitted: 14.06 .2018

Accepted: 10.12 .2018

Published: 15.01.2019

\begin{abstract}
With increasing global requirements for the use of technological tools and resources in K-12 settings, there is a need to examine the technological pedagogical content knowledge (TPACK) levels of mathematics teachers because technology use in class may enhance students' engagement and motivation in learning mathematics. Hence, the purpose of this study was to develop and validate a TPACK scale to be used in investigating mathematics teachers' knowledge levels in TPACK components, and investigate if mathematics teachers' TPACK levels differed in terms of gender, teaching experience and level of school. This study is based on survey research design. Data were collected from 202 mathematics teachers in the spring semester of 2016-2017 academic year. MANOVA was used for data analysis. As a result of exploratory and confirmatory factor analysis, the TPACK instrument was developed as a valid and reliable 39-item 5-point Likert scale consisting of six scales: 1. Technological Knowledge, 2. Pedagogical Knowledge, 3. Content Knowledge, 4. Technological Content Knowledge, 5. Pedagogical Content Knowledge and 6. TPACK. The results also revealed that there were significant differences between gender and technological knowledge domain in favor of male teachers. However, it was found that teaching experience and level of school had no significant effect on TPACK domains.
\end{abstract}

Keywords: Technological pedagogical content knowledge; TPACK; Scale development; Factor analysis; Mathematics teachers

\section{Introduction}

The opportunities and facilities provided by technology make it an indispensable element of daily life. Now, we are living in a time that we cannot even imagine a life without technology (Pamuk, Ulken \& Sener-Dilek, 2012). Technology causes radical changes in many different areas of life particularly in commerce, communication and banking. The results of this situation can be observed in the behavior of individuals, organizations and functioning of institutions. Hence, together with the changes occurring in different layers of society, education system is also affected from these changes. In order to meet individuals' information needs, increasing efficiency in teaching and learning process and offering alternative strategies according to individual differences are some of 
the topics that educators wants to find a solution by integrating technology into education (Pamuk, Ulken \& Sener-Dilek, 2012).

In terms of mathematics education, for meaningful learning, lecturing is considered as insufficient to learn. Hence, in Turkey, constructivist curriculum was implemented which focused on studentcentered and active instruction instead of teacher-centered lecture type of instruction (MoNE, 2013). In the learning environment, the use of different teaching learning methods and materials for effective understanding and active involvement of students in mathematics were seen very important. Similarly, The National Council of Teachers of Mathematics (NCTM) in the United States stated that technology was one of the most important components in teaching and learning of mathematics (Zelkowski, Gleason, Cox \& Bismarck, 2013). Also, it was stated by NCTM that teachers are not only expected to use technology by bringing hardware and software to the class, but provide an environment including appropriate teaching strategies and techniques which facilitate and support students' learning by taking into account students' learning styles and individual differences (Cetin \& Erdogan, 2018).

In addition to these, it was stated by NCTM that in technology-rich classrooms, students can develop multiple representations of concepts, engage in activities with higher motivation. However, instead of using technology to support student's learning, teachers mostly use technology for finding online resources or storing data or making presentations (Kartal \& Cinar, 2018). It was thought that since teachers have not learned mathematics with technology, they mostly do not tend to use technology to teach mathematics, which is the primary reason to conduct the current study in order to investigate what teachers should know to adapt technology effectively to teaching-learning process.

Moreover, Dede and Argun (2003) indicated that in order to overcome the abstractness of mathematics, instruction should contain materials. Although there are different materials including visual, audio-visual, real objects like puzzles, coins, dice, tangrams, computers mobile devices, Web 2.0 tools, social networking sites and different software to increase the effectiveness of teaching and learning process (Landry, 2010), especially technological materials are stated as proper for the students in this century (Zengin- Unal, 2015).

With the increasing global requirements for the use of technological tools and resources in $\mathrm{K}-12$ settings, it is critical to determine teachers' specialized knowledge for effective technology integration which was referred as technological, pedagogical and content knowledge (TPACK) by Koehler \& Mishra (2009). Although some mathematics teachers utilize technology effectively in their classroom practices, others seem to avoid integrating technology. Hence, it was seen important by educators to investigate teachers' perceptions about technology integration (Graham, 2011).

\section{Theoretical Framework}

Effective teaching depends on rich, well-organized and integrated knowledge from different domains including knowledge of student thinking and learning, knowledge of subject matter, and knowledge of technology (Koehler \& Mishra, 2009). Shulman (1986) claimed the domains of content and pedagogy should be combined, rather than looking at each particular domain separately. He further proposed the PCK model consisting of pedagogical knowledge (PK), content knowledge (CK) 
and pedagogical content knowledge (PCK) (cited in Schmidt et al., 2009). The concept of technological, pedagogical and content knowledge (TPACK) was generated from PCK framework developed by Shulman (1986), which referred to technological knowledge contextually situated within content, pedagogical knowledge, and the interrelated knowledge between the two (Schmidt et al., 2009). It can be said that teaching and learning activities make sense more when the technology content and pedagogical knowledge are integrated. As it can be seen in TPACK model shown in Figure 1, the effective use of technology integration is composed of three basic components and as a result of their interaction. The components of TPACK framework are explained below.

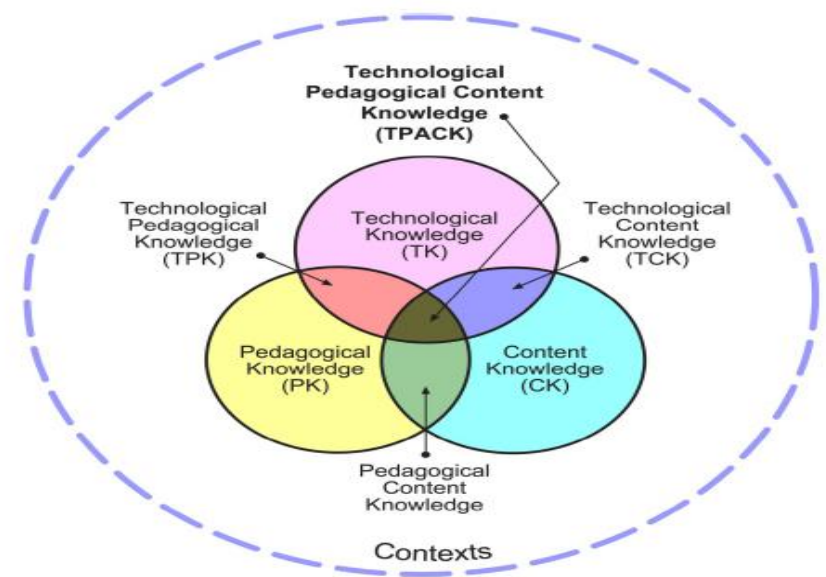

Figure 1. The Framework of TPACK Model (Source: http://www.TPACK.org)

Technological Knowledge (TK) is the knowledge about PowerPoint, multimedia, software, interactive whiteboards and more advanced technologies such as the internet and digital video (Jang \& Tsai, 2013). According to Chai et al. (2011), TK includes the knowledge to be able to use technologies like blackboard, smart board, tablet and Web 2.0 tools (e.g. Wiki, Blogs, Facebook). Besides, Content Knowledge (CK) refers to the amount and organization of knowledge in the mind of the teacher (Shulman, 1986). This knowledge includes facts, concepts, structures and rules that incorporate those facts and concepts. Teachers must have a broad knowledge base of the subject matter so that they can retrieve and teach contents in logical and organized ways (Jang \& Tsai, 2013). Pedagogical Knowledge (PK) is the knowledge about students' learning, instructional methods and materials, different educational theories, lesson plan development, classroom management and assessment procedures (Chai et al., 2011; Schmidt et al., 2009).

Pedagogical Content Knowledge (PCK) is the knowledge that teachers use to transform their content knowledge and help their students develop a deeper understanding of specific subject matter (Shulman, 1986). PCK is concerned with pedagogical techniques, knowledge of what makes concepts difficult or easy to learn, knowledge of students' prior knowledge, and theories for specific contexts (Koehler \& Mishra, 2009). Technological Content Knowledge (TCK) is the knowledge about how to use technology to represent the content in different ways (Chai et al., 2011) such as knowledge about how to use internet games to show the operations about fractions. Technological Pedagogical Knowledge (TPK) is the knowledge for the use of various technologies to enable teaching approaches (Chai et al., 2011). TPK can be used in teaching to change the ways teachers teach (Schmidt et al., 2009). 
Technological Pedagogical Content Knowledge (TPACK) is the knowledge of using various technologies to teach and represent the content. Together with knowledge of technology and awareness of it, teachers are expected to rethink course elements that are difficult to teach in traditional ways, and attempt to transform their instruction into better representations using technologies (Jang \& Tsai, 2013). Teachers who are well-equipped with TPACK do not perceive technology as a delivery vehicle to simply deliver information but as one which integrates content, pedagogy, and technology to facilitate students' knowledge construction.

The TPACK model has been widely used in both quantitative (Chai, Koh \& Tsai, 2011; Mandaci- Sahin, Aydogan-Yenmez, Ozpinar \& Kogce, 2013; Pamuk et al., 2012) and qualitative research studies (Demir \& Bozkurt, 2011; Groth, Spickler, Bergner \& Bardzell, 2009; Mcgrath, Karabas \& Willis, 2011). In recent years, the TPACK model has also been employed to investigate teachers' TPACK development according to different learning contexts such as mathematics (Dikkartin-Ovez \& Akyuz, 2013; Kagizmanli, Tatar \& Zengin, 2013; Mutluoglu, 2012); science (Jang \& Tsai, 2013), physical education (Semiz \& Ince, 2012), English (Kurt, Akyel, Kocoglu \& Mishra, 2014; Solak \& Cakir, 2014).

In the literature, it was seen that a number of TPACK scales have been developed or adapted to different groups of participants including pre-service (Baran \& Canbazoglu-Bilici, 2015; CanbazogluBilici, Yamak, Kavak \& Guzey, 2013; Cetin \& Erdogan, 2018; Dikkartin-Ovez \& Akyuz, 2013; Kaya \& Dag, 2013; Koehler \& Mishra, 2005; Pamuk, Ergun, Cakir, Yilmaz \& Ayas, 2015; Sancar-Tokmak, Incikabi \& Ozgelen, 2013; Schmidt et al., 2009; Zelkowski et al., 2013) and teachers (Altun, 2013; Lee \& Tsai, 2010) to investigate pre-service and in-service teachers' TPACK and its relation with different variables. As it can be seen in the literature, many of the studies concentrated on assessing pre-service teachers' understanding of TPACK but there are a few studies that focused on TPACK of teachers and basically mathematics teachers'. In the case study conducted by Patahuddin, Lowrie and Dalgarno (2016), which investigated the most influential TPACK constructs in understanding and shaping teachers' pedagogical practices using digital technology through examining critical instructional events in an early secondary mathematics classroom in Indonesia, it was found that the teacher demonstrated the domains TCK and PCK; however, the teacher exhibited some TPK and the teacher did not exhibit essential elements of TPACK. This finding suggested that teachers were not sufficient in using TPACK. Also, correlational studies were implemented. For example, Khine, Ali and Afari (2017) found in their study that TK, PK, CK and TPK were significant predictors of TPK, TPACK and PCK, with the exception of CK which did not significantly relate to PCK and also PCK did not significantly relate to TPACK.

In addition, scales for assessing TPACK were developed. The scale developed by Schmidt et al. (2009) is the most adapted one (Canbazoglu-Bilici et al., 2013). Schmidt et al. (2009) developed "Survey of Pre-service Teachers' Knowledge of Teaching and Technology" scale to measure the development and implementation of TPACK. 124 pre-service classroom teachers were included in the study. After conducting EFA and by subtracting 18 items, the final form included valid and reliable 5-point Likert scale consisting of 47 items.

Dikkartin-Ovez and Akyuz (2013) has adapted the Technological Pedagogical Content Knowledge (TPACK) scale developed by Schmidt et al. (2009) into Turkish. The scale applied to 473 elementary mathematics pre-service teachers. Explanatory and confirmatory factor analysis has been carried out to examine the factor structure and reliability coefficient Cronbach alpha for each scale were 
provided. The findings revealed that the scale had a four-factor structure with reliability coefficients of Cronbach's alpha values greater than 0.70 . It was determined that pedagogical knowledge and pedagogical content knowledge factors were not discriminated. Hence, the items of these two subscales were combined as one factor 'Knowledge of Mathematics Teaching'. In addition, since the items of the TPK, TCK and TPACK were classified as another factor 'Knowledge of Technology Integration in Mathematics Teaching'. It can be said that some dimensions of TPACK could not be discriminated by pre-service teachers thus they were classified under new factors.

Kaya and Dag (2013) adapted Survey of Pre-service Teachers' Knowledge of Teaching and Technology" in order to investigate pre-service classroom teachers' TPACK. Their findings showed an eight factor structure. Although there is no change in the number of items, only four of the seven factors of the original scale maintain, the rest three factors were divided into four factors. CK, PCK and TCK sub-scales for science course were combined in the adapted version which was the same case for the social studies, mathematics and applied reading and writing parts.

Moreover, the scale development studies which include teachers as participants from different departments. In the study conducted by Ozturk and Horzum (2011), 291 elementary school teachers from seven primary schools in three central districts of Sakarya participated in the study. Among 291 elementary school teachers, 164 (54.6\%) were classroom teachers, 22 (7.6\%) were Turkish Language teachers, 16 (5.5\%) were Mathematics, 18 (6.2\%) were Science and Technology teachers, $12(4.1 \%)$ were Social Studies teachers. 59 (22.0\%) were the teachers of a variety of other courses like information technologies, religious education, English, pre-school, technological design. However, this study did not include teachers from just one specific department like mathematics teaching to investigate their department specific TPACK levels. Also, the confirmatory factor analysis values were found $\chi 2=2585.11(S D=1003, p=.0001$ ), $\chi 2 / s d=2.58$ RMSEA $=0.074, R M R=0.079$; $\mathrm{SRMR}=0.06, \mathrm{GFI}=0.72, \mathrm{AGFI}=0.70, \mathrm{IFI}=0.97, \mathrm{CFI}=0.97, \mathrm{NFI}=0.94$ and $\mathrm{NNFI}=0.96$, which might be improved for some goodness of fit indices.

One of the qualitative studies was conducted by Kartal and Cinar (2018). The aim of their study was to investigate changes of elementary mathematics pre-service teachers' beliefs about TPACK during a method course and field experience. In their study, six pre-service teachers were selected purposefully with reference to their technological and mathematical backgrounds and they were interviewed five times (beginning of the study, after workshops, after method course, beginning and end of field experience). After content analysis, it has been found that pre-service teachers perceived the role of technology as a visualization tool at the beginning of the study but any of them connected the effect of visualization on students' learning even after the workshop. Moreover, some of the pre-service teachers argued that technology cannot be used for all mathematics topics but they insisted on the integration of technologies' being useful for some topics which can be visualized like geometry. Since pre-service teachers had a limited beliefs about instructional strategies to teach with technology, they emphasized that technology should be used to support concepts after those concepts were mastered. Moreover, they noticed the importance of dynamic geometry software in simplifying drawing more and accurate diagrams. Also, pre-service teachers noticed that technology let them propose more and different examples in short time, which promotes and makes learning easier by avoiding rote learning. Also, it was found that pre-service teachers who have low level technological self-assessments firstly mentioned about their classroom management concerns. 
The Ministry of National Education in Turkey is expecting technology integration. By providing budget for the Movement of Enhancing Opportunities and Improving Technology (FATIH) project, the integration of technology to teaching-learning process was intended to be increased (Ocak, Gokcearslan \& Solmaz, 2014). However, besides providing budget for software and hardware, technology integration requires teachers to have necessary competencies to use that technology effectively (Saralar, 2016). Hence, it was assumed to be important to know how to use technology effectively by combining content knowledge, pedagogy and technology.

Also, the results of the studies conducted with pre-service teachers indicated that increased TPACK resulted in enhanced teachers' knowledge and skills regarding combining technology with pedagogy in classroom settings. Thus, there is a need to examine the perceptions of mathematics teachers about the integration of technology in mathematics. Moreover, if the relationship between the TPACK constructs and the teacher demographic variables are investigated, it may provide information for the planning of teacher development programs.

As Chai et al. (2011) asserted, teachers' TPACK perceptions are influenced by different factors. There have been several studies indicating teachers' differences on TPACK domains by gender, age and level of school (Erdogan \& Sahin, 2010; Jang \& Tsai, 2013; Lee \& Tsai, 2010; Luik, Taimalu \& Suviste (2018). Erdogan and Sahin (2010) study, which examined pre-service mathematics teachers' TPACK, found that male teachers perceived all TPACK components significantly higher than female teachers. Also, males rated their knowledge higher than females in most domains except PK and PCK. Moreover, Bulut (2012) found statistically significant differences in favor of male participants in the TK, TPK and TPACK dimensions. In contrast, Ozturk (2013) found that classroom teachers' TK and CK did not change according to gender but the mean of female pre-service students was significantly higher than male students in terms of PK. Altun (2013) found that female teachers' CK, PK, PCK and TCK scores were significantly higher than those of the male teachers. Similarly, Karaca (2015) found that pre-service teachers studying at computer and instructional technologies education had different TPACK scores based on gender. Female pre-service teachers had higher TPACK values than males. However, there are studies that conclude gender does not cause a significant difference in TPACK (Acikgul \& Aslaner, 2015; Jang \& Tsai, 2013; Mutluoglu, 2012). Jang and Tsai (2013) revealed that TPACK of elementary science and mathematics teachers indicated no significant gender differences in terms of technology use. Similarly, Mai and Hamzah (2016) found no differences between science teachers' perceptions according to their gender. In addition, Acıkgul and Aslaner (2015) as well as Koh and Sing (2011) found that pre-service teachers' TPACK confidence did not differ significantly with regard to gender. Hence, it was thought important to investigate TPACK levels of mathematics teachers according to gender and if there are significant differences, some precautions should be taken like in-service training in terms of improving mathematics teachers' TPACK.

In addition, research on TPACK by teaching experience suggest varying results. Jang and Tsai (2013) found that more experienced elementary science and mathematics teachers' CK, PCK, TCK and overall TPACK were significantly higher than less experienced teachers. Similarly, Altun (2013) found that the mean scores of teachers who had 16 and more years of teaching experience were significantly higher than the mean scores of those teachers who had teaching experience of between 0 and 15 years. In contrast, Mutluoglu (2012) determined differentiation at TK levels 
according to mathematics teachers' teaching experience. Teachers who had more teaching experience had less TK. Similarly, Jordan (2013) found that the beginning teachers generally rated their TPACK knowledge highly, particularly in relation to their CK. Besides, Lee and Tsai (2010) found that both the participants' age and their teaching experience had a significantly negative relationship to their self-efficacy regarding TPACK knowledge. It was indicated that senior teachers had relatively low confidence in all aspects of the TPACK. In Luik, Taimalu and Suviste's study (2018), statistically significant negative relationships were found between age and TK and positive relationships between age and CK, but PK was not significantly related to age. As it can be seen, in terms of TPACK and its dimensions, teaching experience and age are important variables that need to be researched.

Also, research on TPACK suggested varying results according to level of schools. In the study conducted by Erdogan and Sahin (2010), pre-service mathematics teachers' technological pedagogical and content knowledge (TPACK) was analyzed based on their level of school. The results of the study showed that there were significant differences between primary and secondary mathematics teacher candidates' TPACK domains. It was displayed that elementary mathematics teacher candidates' TPACK level was significantly higher than that of prospective secondary mathematics teachers. However, Kagizmanli et al. (2013) did not find a significant difference according to the level of schools for TPACK constructs. Hence, it was thought important to investigate TPACK levels of mathematics teachers according to teaching experience.

The purpose of this study was to develop and validate a TPACK scale to be used in investigating mathematics teachers' knowledge levels in TPACK components. Furthermore, this study aimed to investigate if mathematics teachers' TPACK levels differed in terms of gender, teaching experience and level of school including primary and secondary mathematics. Based on the main purpose of the study, the following research questions were proposed:

1. Is the scale developed in the current study valid and reliable to measure mathematics teachers' knowledge levels about TPACK components?

2. What are the effects of gender, teaching experience and school level on mathematics teachers' TPACK perceptions?

\section{Methodology}

\section{Research Design}

This study was based on survey research design. Survey research designs are procedures in quantitative research in which investigators administer a survey to a sample to describe the attitudes, opinions, behaviors, or characteristics of the population (Creswell, 2012). According to Fraenkel and Wallen (2009), in survey design researchers collect information from a sample that has been drawn from a pre-determined population at just one point in time. The meaning of the data is interpreted by relating results of the statistical test back to past research studies. 


\section{Participants}

The participants of this study included a total of 202 mathematics teachers working in middle and high schools in a city located in the Aegean Region. Among the 202 mathematics teachers, 88 (43.6 $\%)$ were female and 114 (56.4\%) were male, and 75 (37.1\%) were teaching at a middle school and 127 (62.9\%) were teaching at a secondary school. Finally, 25 (12.4\%) of the participating teachers had 1 to 5 years of experience, 49 (24.3\%) had 6 to 10 years of experience, $44(21.8 \%)$ had 11 to 15 years of experience, 53 (26.2\%) had 16 to 20 years of experience and 31 (15.3\%) had 21 to 25 years of experience.

\section{Data Collection and Instrumentation}

Data were collected in the spring semester of 2016-2017 academic year. Teachers' TPACK scale was developed to collect data about teachers' self-assessment of their seven knowledge domains within the TPACK framework.

The development process of the scale began with literature review, and proceeded with item generation. A total of 54 items was written by reviewing the related literature mainly Kaya and Dag (2013), Ozturk and Horzum (2011), Pamuk et al. (2015), and Schmidt et al. (2009). Then, the draft scale was presented to the views of three experts, one of whom was from the Department of Computer Education and Instructional Technology and two of whom were from the Department of Curriculum and Instruction, to analyze it and make some recommendations. As a result, six items were omitted and some items were rephrased.

Having obtained experts' opinion, three mathematics teachers were also consulted to check clarity of the items. After conducting necessary corrections, final form of the scale was reached. In this study, the draft scale composed of two parts; the first part involved demographic information and the second part involved 48 items about TPACK framework. The second part consisted of seven subsections including TK-7 items, CK-7 items, PK-9 items, PCK-6 items, TCK-6 items, TPK-6 items and TPACK-7 items. The scale was organized as a 5-point Likert-type scale ranging from certainly disagree (1), disagree (2), neither agree nor disagree (3), agree (4) and completely agree (5).

\section{Data Analysis}

In this study, TPACK framework that contained three core types of knowledge; CK, PK, and TK, and four interrelated types of knowledge between the three core types of knowledge; PCK, TCK, TPK, and TPACK were dependent variables. Gender, years of experience of mathematics teachers and the level of schools that these teachers teach were independent variables.

The construct validity of the scale was determined by 'Exploratory Factor Analysis' (EFA) and 'Confirmatory Factor Analysis' (CFA). While for EFA SPSS was used, Lisrel 8.8 was used for CFA. For EFA, multivariate analysis method was applied in order to extract the underlying factors of the TPACK instrument. Oblique rotation was employed because the factors of the scale were likely to 
correlate with each other. The Barlett test result and KMO coefficient was determined for the applicability of data for factor analysis.

In addition, the Principle axis factoring (PAF) extraction method, which was more appropriate than Maximum likelihood factor method, was employed because multivariate normality was violated as a result of the Mardia's test (Feldt, Graham \& Dew, 2011). Oblique rotation, namely promax was conducted to determine the validity of the structure of the TPACK scale (Field, 2009).

Furthermore, the reliability for seven TPACK subscales was determined by Cronbach's alpha coefficient. According to Field (2009), 0.8 is a generally accepted value for cognitive tests while 0.7 is more suitable cut-off point for ability tests. Also, only factors with eigenvalues greater than 1 was retained (Tabachnick \& Fidell, 2007).

In addition to these, the factor structure of the TPACK instrument was confirmed by Confirmatory Factor Analysis (CFA). CFA was performed by using the estimation method of Maximum Likelihood with robust standard errors (MLR), because multivariate normality assumptions were not met. The model fit was evaluated by model Chi-square, RMSEA (Root Mean Square Error of Approximation), CFI (Comparative Fit Index), GFI (Goodness of Fit Index), IFI (Incremental Fit Index), NFI (Normed Fit Index), NNFI (Non-Normed Fit Index) as suggested by Hair, Black, Babin and Anderson (2010).

Moreover, in order to examine the effect of gender, teaching experience and level of school on teachers' TPACK knowledge, MANOVA was used because there were more than three dependent variables (Tabachnick \& Fidell, 2007). For MANOVA analyses, SPSS 22.0 was used. Alpha level was determined as .05 for analysis.

\section{Results}

\section{Exploratory Factor Analysis (EFA)}

In order to ensure the validity and reliability of the TPACK scale, EFA was performed. First of all, missing data were checked and influential outliers and the assumptions of EFA namely, univariate normality, multivariate normality, linearity, multi-collinearity and outliers were controlled.

In this study, the KMO value of the data set was checked and found 0.92 . Hence, according to Kaiser (1974), it can be said that sample size is adequate for factor analysis (cited in Field, 2009). Moreover, Bartlett's test is significant $X^{2}(d f=861)=5987.60, p<.0001$. Hence, it can be said that the data as a whole is appropriate for factor analysis. EFA, which was conducted by using Principal Axis Factoring (PAF) and promax rotation technique, resulted in six-factor structure. Out of 48 items, items 16, 18, $23,25,26$ and 36 were removed from the scale because of cross-loading and weak loading. The subdimensions of the scale were named TK (technological knowlege), CK (content knowledge), PK (pedagogical knowledge, TCK (technological content knowledge), PCK (pedagogical content knowledge) and TPACK. 


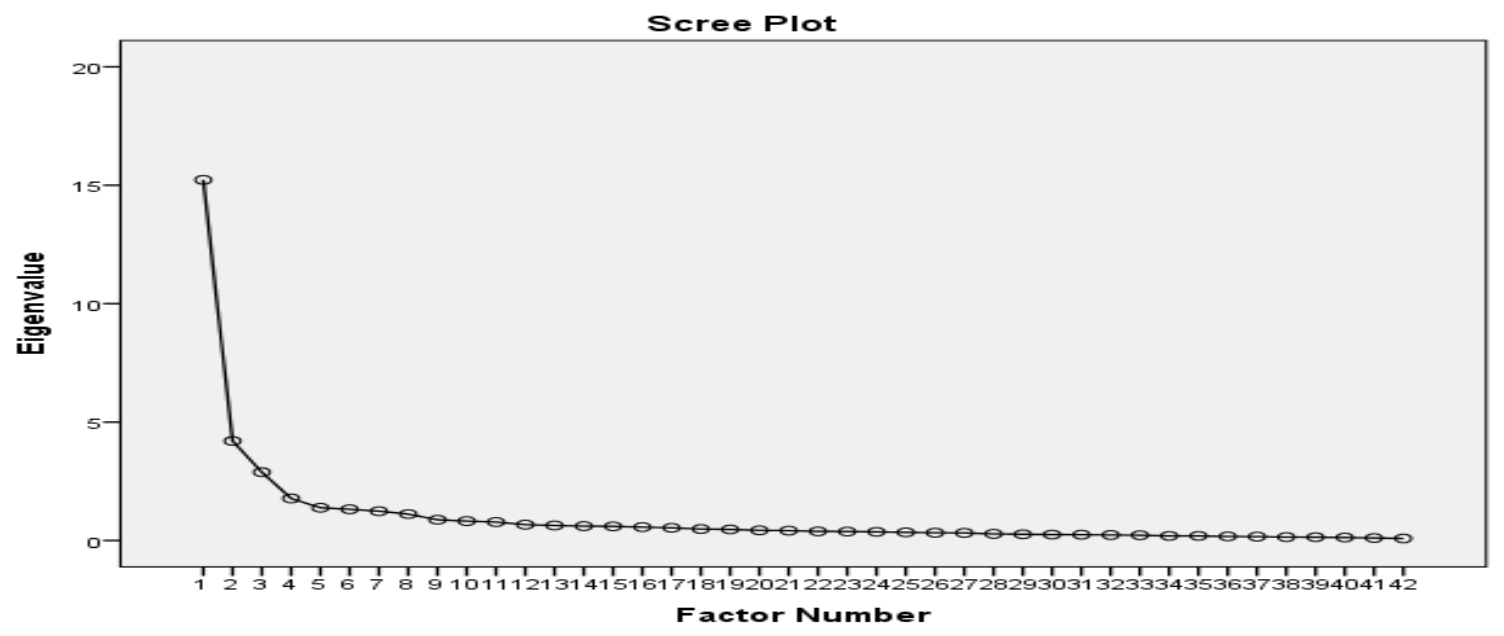

Figure 2. Scree Plot for TPACK Scale

In this study, factors with eigenvalues greater than 1 were retained. In the scree-plot, the factors with large eigenvalues can be observed by the sharp descent in the curve followed by a tailing off (Field, 2009). Hence, by examining theoretical structure, as well as the scree plot, six factors were retained.

The factors explained $36.25 \%, 10.00 \%, 6.87 \%, 4.23 \%, 3.30 \%$ and $3.14 \%$ of the total variance respectively. The percentage of the six factors to explain the total variance was $63.79 \%$. Moreover, the eigenvalues of the factors varied from 15.22 to 1.32 . The eigenvalues and percentages of the explained variance were displayed in Table 1.

Table 1. Eigenvalues, Percentages of Variance and Cumulative Percentages for Factors of the TPACK Scale

\begin{tabular}{cccc}
\hline Factor & Eigenvalue & \% of Variance & Cumulative \% \\
\hline 1 & 15.22 & 36.25 & 36.25 \\
2 & 4.20 & 10.00 & 46.26 \\
3 & 2.89 & 6.87 & 53.12 \\
4 & 1.78 & 4.23 & 57.35 \\
5 & 1.38 & 3.30 & 60.65 \\
6 & 1.32 & 3.14 & 63.79 \\
\hline
\end{tabular}

Pattern matrix was checked in order to examine the factor loadings of the items. Only items with factor loadings 0.3 or higher on its own scale were considered in deciding the factor structure of each scale (Field, 2009; Stevens, 1992). The factor loadings for the TPACK scales were presented in Table 2. 
Table 2. Factor Loadings for Promax Six-factor Solution for the TPACK Instrument

\begin{tabular}{|c|c|c|c|c|c|c|}
\hline \multirow[b]{2}{*}{ Items } & \multicolumn{6}{|c|}{ Factor } \\
\hline & 1 & 2 & 3 & 4 & 5 & 6 \\
\hline s1 & .25 & .65 & -.05 & -.02 & .02 & -.12 \\
\hline s2 & .05 & .54 & -.04 & .15 & .08 & -.02 \\
\hline s3 & -.09 & .78 & .17 & -.13 & .12 & .04 \\
\hline s4 & -.05 & .82 & -.06 & .06 & -.02 & -.00 \\
\hline s5 & -.13 & .91 & .11 & -.06 & -.04 & .01 \\
\hline s6 & .02 & .89 & .04 & -.03 & -.00 & -.09 \\
\hline s7 & .01 & .81 & -.14 & .01 & -.02 & .13 \\
\hline s8 & .13 & .10 & .55 & -.11 & .02 & .01 \\
\hline s9 & -03 & -.03 & .59 & .15 & -.02 & .08 \\
\hline s10 & .02 & -.16 & .74 & -.03 & .05 & -.10 \\
\hline s11 & .23 & .12 & .31 & .25 & -.17 & .05 \\
\hline s12 & .05 & .07 & .41 & .20 & -.17 & .12 \\
\hline s13 & .01 & .10 & .50 & -.01 & -.07 & .11 \\
\hline s14 & -.13 & .13 & .67 & .11 & -.06 & .06 \\
\hline s15 & .10 & .01 & .70 & -.07 & .00 & .00 \\
\hline s17 & .01 & .02 & .03 & .80 & -.07 & -.02 \\
\hline s19 & -.01 & .00 & -.13 & .90 & -.00 & -.03 \\
\hline s20 & -.00 & -.12 & .05 & .79 & .13 & -.09 \\
\hline$s 21$ & -.10 & -.02 & .24 & .63 & .10 & .04 \\
\hline s22 & -.08 & .05 & .20 & .61 & .01 & -.05 \\
\hline s24 & .63 & .01 & .12 & .01 & .11 & -.18 \\
\hline s27 & .90 & -.11 & -.09 & -.05 & -.07 & .12 \\
\hline$s 28$ & .69 & -.08 & .09 & -.15 & .05 & .12 \\
\hline$s 29$ & .33 & -.07 & .19 & -.11 & .51 & -.17 \\
\hline s30 & .03 & .06 & -.06 & -.05 & .81 & .04 \\
\hline s31 & .15 & .03 & .04 & -.02 & .67 & -.03 \\
\hline s32 & .01 & -.02 & -.11 & .11 & .86 & -.04 \\
\hline s33 & .10 & .10 & -.11 & .14 & .53 & .17 \\
\hline s34 & .52 & .02 & -.18 & .09 & .08 & .24 \\
\hline s35 & .47 & -.15 & .24 & .11 & -.13 & .14 \\
\hline s37 & -.15 & -.20 & .31 & .03 & .27 & .45 \\
\hline s38 & -.20 & -.03 & .15 & -.12 & .18 & .82 \\
\hline s39 & .10 & .01 & .15 & -.04 & -.04 & .69 \\
\hline s40 & .13 & .03 & .00 & .01 & -.21 & .88 \\
\hline s41 & .20 & .15 & -.14 & .12 & .12 & .41 \\
\hline s42 & .34 & .02 & .15 & .06 & .22 & .13 \\
\hline s43 & .42 & .17 & .05 & .01 & .21 & .07 \\
\hline s44 & .77 & -.00 & .13 & .02 & -.02 & -.05 \\
\hline s45 & .73 & .01 & .07 & .04 & .06 & -.14 \\
\hline s46 & .87 & .03 & .04 & -.07 & -.02 & -.01 \\
\hline s47 & .90 & -.03 & -.21 & .06 & .04 & .04 \\
\hline s48 & .79 & .10 & .01 & -.03 & -.08 & -.08 \\
\hline
\end{tabular}


Factor Correlations

$\begin{array}{lcccccc}\text { Factor1 } & 1.00 & & & & & \\ \text { Factor2 } & .53 & 1.00 & & & & \\ \text { Factor3 } & .48 & .37 & 1.00 & 1.00 & & \\ \text { Factor4 } & .37 & .31 & 62 & .48 & 1.00 & \\ \text { Factor5 } & .63 & .41 & .48 & .63 & .51 & 1.00 \\ \text { Factor6 } & .47 & .37 & .63 & .63\end{array}$

Finally, the correlations between TPACK subscales were investigated and it was found that the lowest correlations were between factor $2=T K$ and factor $4=C K(r=.31)$. The highest correlations were between factor $1=$ TPACK and factor $5=$ TCK; factor $3=\mathrm{PK}$ and factor $6=\mathrm{PCK}$; factor $4=\mathrm{CK}$ and factor $6=$ PCK all with the correlation coefficient of $r=.63$.

According to Table 2, items $24,27,28,34,3542,43,44,45,46,47,48$ were loaded to the $1^{\text {st }}$ factor ranging from .34 to .90 . The $1^{\text {st }}$ factor was named as "TPACK". Items 1, 2, 3, 4, 5, 6 and 7 were loaded to the $2^{\text {nd }}$ factor ranging from .54 to .91 and the name of $2^{\text {nd }}$ factor was "TK". Items $8,9,10,11,12$, 13,14 , and 15 were loaded to the $3^{\text {rd }}$ factor ranging from .50 to .74 . The $3^{\text {rd }}$ factor was named as "PK". In addition, items 17, 19, 20, 21 and 22 were loaded to the $4^{\text {th }}$ factor ranging from .61 to .90 . The 4th factor was named as "CK". The items 29, 30, 31, 32 and 33 were loaded to the $5^{\text {th }}$ factor ranging from .52 to .86 . The $5^{\text {th }}$ factor was named as "TCK". Finally, the items $37,38,39,40$ and 41 were loaded to the $6^{\text {th }}$ factor ranging from .41 to .88 . The $6^{\text {th }}$ factor was named as "PCK".

\section{Confirmatory Factor Analysis}

The factor structure of the TPACK Instrument was confirmed by CFA by using MLR because multivariate normality assumptions were not met. CFA proposed the fit index: $X^{2}(d f=685)=1369.44$, $\mathrm{p}<.0001, \mathrm{RMSEA}=.07, \mathrm{CFI}=.96, \mathrm{NFI}=.93, \mathrm{IFI}=.96, \mathrm{GFI}=.74$.

In the present data set, according to CFA results items 6,46 and 47 were removed respectively because of weak loading. Then, modification indices were checked to see whether it was possible to improve the model fit. Error covariances were examined and the item pairs 8-9 and 13-14 were observed with high covariances. Items 8 and 9 were both the items of the same construct, which was the third factor in the scale. Afterwards, CFA was re-run and modifications were conducted to improve model fit among item pairs 13-14.

CFA was re-run after the modifications and the following model fit indices were proposed. $X^{2}(\mathrm{df}=$ $685)=1388.70, p<.0001$. The value of $X^{2} / d f=2.03(p<.0001)$ is less than 3 . The acceptable value for the $\mathrm{X}^{2} / \mathrm{df}$ should be non-significant and should be less than 3 . Since it was significant, other goodness of fit indices were checked. RMSEA $=.071, \mathrm{CFI}=.96, \mathrm{NFI}=.93, \mathrm{NNFI}=.96, \mathrm{IFI}=.96, \mathrm{RFI}=.92$ and $\mathrm{GFI}=$ .74. For the model fit indices CFI, IFI, NNFI, NFI, RFI, the acceptable values are .90 or above, and values above .95 are accepted as superb. However, as for the GFI the values 0.85 or above are acceptable. Moreover, the acceptable values for RMSEA are between .050 and .080 and values between .00 and .05 are accepted as superb. (Hair et al., 2010). Except GFI, other goodness of fit indices were among the acceptable values namely they indicated moderate or superb fit. Unstandardized estimates of path coefficients showed that indicators' loadings on the associated 
factors were statistically significant at $p=.001$ level, which meant that each item significantly contributed to the corresponding factors. The standardized path coefficients ranged from 0.27 for items 3 and 21 to 0.69 for item 35 . Figure 3 showed the standardized path coefficients for six-factor model of the TPACK Instrument.

Figure 3. Standardized Path Coefficients for Six-factor Model of TPACK Instrument

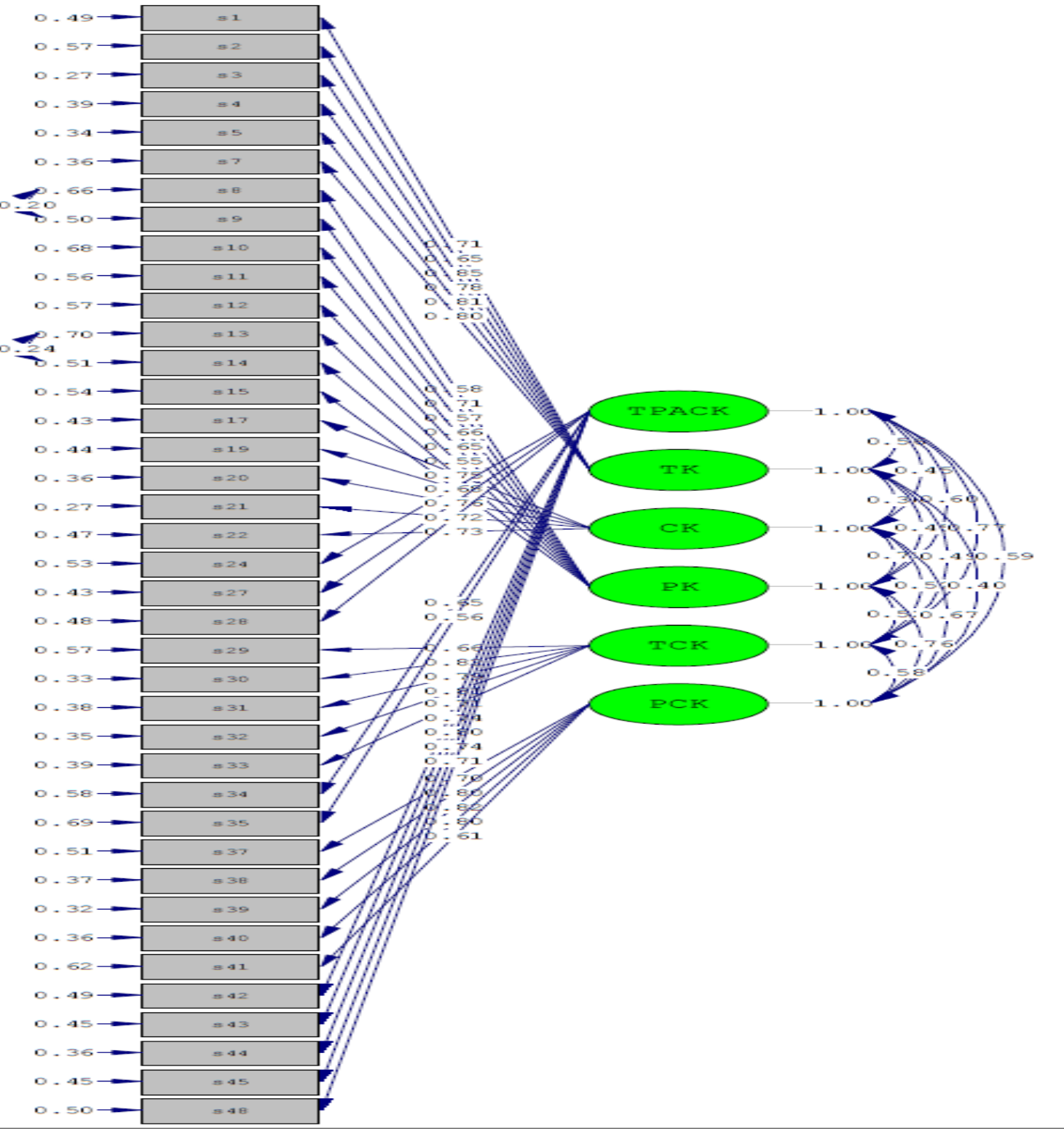

Note: All coefficients are significant at $\mathrm{p}<.001$, factor $1=\mathrm{TPACK}$. factor $2=\mathrm{TK}$, factor $3=\mathrm{PK}$, factor $4=\mathrm{CK}$, factor $5=$ TCK, and factor6 $=$ PCK. 
The reliability coefficient was found 0.91 for TPACK, 0.89 for TK, 0.85 for PK, .89 for CK, 0.88 for TCK and .86 for PCK scales. The reliability coefficients of the scales were found to be greater than .70 , which indicated high reliability (Nunnally, 1970 cited in Field, 2009).

As a result, items $24,27,28,34,35,42,43,44,45,48$ were loaded to the $1^{\text {st }}$ factor "TPACK". Items $1,2,3,4,5$, and 7 were loaded to the $2^{\text {nd }}$ factor "TK". Items $8,9,10,11,12,13,14$, and 15 were loaded to the $3^{\text {rd }}$ factor "PK". In addition, items 17, 19, 20, 21 and 22 were loaded to the $4^{\text {th }}$ factor "CK". The items 29, 30, 31, 32 and 33 were loaded to the $5^{\text {th }}$ factor "TCK". Finally, the items 37, 38, 39,40 and 41 were loaded to the $6^{\text {th }}$ factor "PCK".

The TPACK instrument was developed as a valid and reliable 39-item 5-point (ranging from 1completely disagree to 5 - completely agree) Likert scale consisting of six scales. TPACK scale consisted of 10 items; TK scale consisted of 6 items; PK scale included 8 items; CK scale included 5 items; TCK scale consisted of 5 items and PCK scale included 5 items.

Table 3. Factors and Item Numbers

\begin{tabular}{lll}
\hline Factors & Total Item & Items \\
\hline TPACK & 10 & $24,27,28,34,35,42,43,44,45,48$ \\
TK & 6 & $1,2,3,4,5,7$ \\
PK & 8 & $8,9,10,11,12,13,14,15$ \\
CK & 5 & $17,19,20,21,22$ \\
TCK & 5 & $29,30,31,32,33$ \\
PCK & 5 & $37,38,39,40,41$ \\
Total & 39 & \\
\hline
\end{tabular}

\section{Results Regarding Teachers' Level of TPACK and Effects of Gender, Teaching Experience and School Level on Their TPACK Perceptions}

Before conducting MANOVA, which was run to find out the effect of gender, teaching experience and school level on teachers' TPACK perceptions, univariate and bivariate normality, multivariate normality, homogeneity of covariance and homogeneity of variance assumptions of MANOVA were checked. In this study, Mardia's test results indicated a significant pattern $(p<.05)$. That means multivariate normality assumption is violated for MANOVA (Tabachnick \& Fidell, 2007).

Moreover, homogeneity of variance assumption was checked with Levene's Test to determine whether the variances in different groups were equal (Field, 2009). According to the results of Levene's test, the homogeneity of variance assumption was not violated for the dependent variables which are TK, $F(19,182)=1.28, p>.05 ; P K, F(19,182)=1.46, p>.05 ; C K, F(19,182)=1.61, p>.05$; $\operatorname{TCK} F(19,182)=1.53, p>.05 ; p>.05 ; \operatorname{TPACK} F(19,182)=1.49, p>.05$. However, the homogeneity of variance assumption for $P C K$ was violated $F(19,182)=1.79$. Hence, the alpha level was determined as .04 as stated by Field (2006).

Furthermore, homogeneity of covariance assumption was checked with Box's test (Field, 2009). The result of Box's test should be non-significant if the matrices are same (Tabachnick \& Fidell, 2007). In this study, Box's $M=411.11, F(252,11353.14)=1.25, p<.05$. Hence, homogeneity of covariance 
assumption was violated and since the multivariate normality assumption was violated Pillai's Trace values was reported in order to check the significance of the MANOVA model. Before interpreting the results for MANOVA, descriptive statistics were explained in Table 4.

Table 4. Mean Scores and Standard Deviations for TPACK Instrument as Functions of TK, PK, CK, TCK, PCK and TPACK Scales

\begin{tabular}{|c|c|c|c|c|c|c|c|c|c|c|c|c|c|c|}
\hline & & & TK & & PK & & CK & & TCK & & PCK & & TPACK & \\
\hline $\begin{array}{l}\text { School } \\
\text { Level }\end{array}$ & Exp. & $\mathrm{G}$ & $M$ & $S D$ & $M$ & $S D$ & $M$ & $\begin{array}{l}S \\
D\end{array}$ & $M$ & $S D$ & $M$ & $S D$ & $M$ & $S D$ \\
\hline \multirow{10}{*}{ 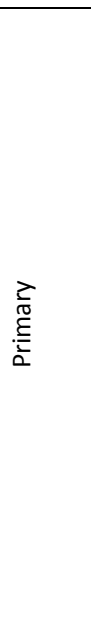 } & $\begin{array}{l}1-5 \\
\text { years }\end{array}$ & $\mathrm{F}$ & 22.00 & 3.82 & 35.00 & 3.44 & 22.15 & 2.82 & 21.27 & 3.85 & 21.27 & 3.69 & 41.36 & 6.54 \\
\hline & & $M$ & 25.00 & 5.0 & 39.00 & 1.00 & 21.33 & 1.15 & 22.67 & 1.53 & 24.00 & 1.00 & 44.00 & 4.58 \\
\hline & $6-10$ & $F$ & 22.33 & 3.64 & 32.67 & 2.58 & 23.00 & 2.39 & 21.73 & 2.52 & 21.13 & 2.75 & 41.53 & 3.00 \\
\hline & & $M$ & 24.60 & 3.37 & 33.58 & 3.63 & 22.67 & 2.35 & 21.17 & 2.69 & 21.67 & 2.39 & 40.42 & 5.93 \\
\hline & $\begin{array}{l}11-15 \\
\text { years }\end{array}$ & $\mathrm{F}$ & 23.00 & 5.35 & 35.25 & 3.95 & 23.25 & 2.06 & 21.75 & 2.36 & 22.75 & 2.63 & 40.75 & 6.50 \\
\hline & & $M$ & 24.60 & 3.37 & 34.40 & 3.78 & 22.30 & 2.31 & 20.80 & 4.57 & 21.60 & 2.80 & 41.12 & 5.83 \\
\hline & $16-20$ & $\mathrm{~F}$ & 19.33 & 6.35 & 32.33 & 5.51 & 23.00 & 2.65 & 21.67 & 3.51 & 21.33 & 3.79 & 41.33 & 6.43 \\
\hline & & $M$ & 25.50 & 2.07 & 34.13 & 2.90 & 23.00 & 2.69 & 21.25 & 2.18 & 22.13 & 1.64 & 41.12 & 3.83 \\
\hline & $\begin{array}{l}21+ \\
\text { years }\end{array}$ & $\mathrm{F}$ & 23.00 & 6.16 & 34.75 & 3.40 & 23.50 & 2.38 & 22.25 & 2.63 & 22.75 & 1.89 & 41.75 & 5.32 \\
\hline & & $\mathrm{M}$ & 22.40 & 5.17 & 34.80 & 2.17 & 22.60 & 2.07 & 21.80 & 1.48 & 21.60 & 0.89 & 42.80 & 5.49 \\
\hline \multirow{10}{*}{ 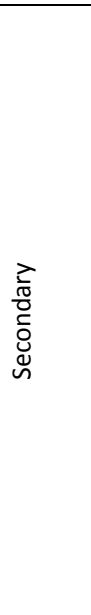 } & $\begin{array}{l}1-5 \\
\text { years }\end{array}$ & $\mathrm{F}$ & 19.00 & 6.04 & 28.40 & 7.40 & 18.60 & 6.88 & 18.80 & 5.07 & 19.60 & 5.03 & 32.80 & 8.93 \\
\hline & & $M$ & 21.33 & 5.50 & 31.67 & 6.68 & 20.17 & 4.07 & 19.00 & 4.56 & 18.67 & 2.94 & 36.17 & 4.92 \\
\hline & $6-10$ & $\mathrm{~F}$ & 22.33 & 3.58 & 35.50 & 3.85 & 22.75 & 2.73 & 20.83 & 2.82 & 22.83 & 2.25 & 37.33 & 8.54 \\
\hline & & $M$ & 24.20 & 5.12 & 34.40 & 4.33 & 23.10 & 2.69 & 21.30 & 3.47 & 22.30 & 2.54 & 42.30 & 6.41 \\
\hline & $\begin{array}{l}11-15 \\
\text { vears }\end{array}$ & $\mathrm{F}$ & 21.36 & 3.93 & 33.29 & 4.27 & 23.50 & 2.02 & 21.43 & 3.46 & 21.29 & 2.76 & 38.86 & 7.76 \\
\hline & & $M$ & 24.44 & 6.05 & 33.19 & 3.25 & 23.56 & 1.55 & 20.69 & 1.85 & 20.81 & 1.64 & 40.75 & 4.00 \\
\hline & $16-20$ & $\mathrm{~F}$ & 21.00 & 2.68 & 33.55 & 2.94 & 23.09 & 2.12 & 20.27 & 3.16 & 21.73 & 3.04 & 37.18 & 5.70 \\
\hline & & $M$ & 25.03 & 4.50 & 34.45 & 3.75 & 22.29 & 2.56 & 21.61 & 3.06 & 21.48 & 2.97 & 39.16 & 6.60 \\
\hline & $21+$ & $\mathrm{F}$ & 20.22 & 2.54 & 34.22 & 3.87 & 22.89 & 2.26 & 19.44 & 3.17 & 21.78 & 1.79 & 37.78 & 4.30 \\
\hline & & $M$ & 21.77 & 4.97 & 32.85 & 2.30 & 22.15 & 2.37 & 20.77 & 2.28 & 20.85 & 2.38 & 38.54 & 6.25 \\
\hline
\end{tabular}

In Table 4, it was revealed that teachers teaching at primary schools perceived their TK more than the teachers teaching at secondary schools. Male teachers who taught at primary school and had teaching experience between $16-20$ years perceived their TK highest $(M=25.50, S D=2.07)$, on the other hand, female teachers who taught at secondary school and had teaching experience between 1-5 years perceived their TK lowest $(M=19.00, S D=6.04)$.

In addition, teachers who taught at primary school perceived their PK more than the teachers teaching at secondary schools. Also, male teachers who taught at primary and secondary schools 
perceived their PK more than female teachers. Male teachers who taught at primary school and had teaching experience between 1-5 years perceived their PK highest $(M=39.00, S D=1.00)$. On the other hand, female teachers who taught at secondary school and had teaching experience between 1-5 years perceived their PK lowest $(M=28.40, S D=7.40)$.

Furthermore, female teachers who taught at primary school perceived their CK higher than male teachers but female teachers who taught at secondary school perceived their CK lower than male teachers. Male teachers who taught at secondary school and had teaching experience between 1115 years perceived their $C K$ highest $(M=23.56, S D=1.55)$ which was followed by the female teachers who taught at primary school and had teaching experience over 21 years perceived their CK higher $(M=23.50, S D=2.38)$. On the other hand, female teachers who taught at secondary school and had teaching experience between 1-5 years perceived their $C K$ lowest $(M=18.60, S D=5.07)$.

Besides, teachers who taught at primary school perceived their TCK more than the teachers teaching at secondary school. Moreover, female teachers who taught at primary school perceived their TCK higher than male teachers but female teachers teaching at secondary school perceived their TCK lower than male teachers. Male teachers who taught at primary school and had teaching experience between 1-5 years perceived their TCK highest $(M=22.67, S D=1.53)$. On the other hand, female teachers who taught at secondary school and had teaching experience between 1-5 years perceived their TCK lowest ( $M=18.80, S D=5.07)$.

What is more, teachers who taught at primary school perceived their PCK more than the teachers teaching at secondary school. Male teachers who taught at primary school and had teaching experience between 1-5 years perceived their PCK highest $(M=24.00, S D=1.00)$ and male teachers who taught at secondary school and had teaching experience between 1-5 years perceived their PCK lowest ( $M=18.67, \mathrm{SD}=2.94)$.

It was also unearthed that teachers who taught at primary schools perceived their TPACK more than the teachers teaching at secondary school. Male teachers who taught at primary school and had teaching experience between 1-5 years perceived their TPACK highest $(M=44.00, S D=4.58)$, on the other hand, female teachers who taught at secondary school and had teaching experience between 1-5 years perceived their TPACK lowest ( $M=32.80, S D=8.93)$.

Since it was found that multivariate normality assumption was violated, Pillai's Trace values were included to check the significance of the MANOVA model. Within the MANOVA analyses, first the interaction between independent variables was checked and as it was shown in Table 5 , the interaction was found insignificant $F(6,177)=.69, p>.05$. Hence, the values of interactions were not interpreted and each independent variable and their effects on dependent variables were interpreted. Among the independent variables, gender had a significant effect on dependent variable which is $\operatorname{TK}(F(6,177)=2.69, p<.05)$, but the level of school variable $(F(6,177)=2.07$, $p>.05)$ and teaching experience variable $(F(6,177)=1.03, p>.05)$ did not have a significant effect on the dependent variables. 
Table 5. Multivariate and Univariate Analyses for Gender, Level of School and Teaching Experience on Teachers' Perception of TPACK Scale

\begin{tabular}{|c|c|c|c|c|c|c|c|}
\hline \multirow[b]{2}{*}{ Variable } & \multirow[b]{2}{*}{$\begin{array}{l}\text { MANOVA } \\
F(6,177)\end{array}$} & \multicolumn{3}{|c|}{ ANOVA $F(1,182)$} & \multirow[b]{2}{*}{ TCK } & \multirow[b]{2}{*}{ PCK } & \multirow[b]{2}{*}{ TPACK } \\
\hline & & TK & PK & CK & & & \\
\hline Gender & $2.69 *$ & $10.21 *$ & 1.41 & .35 & .09 & .09 & 2.26 \\
\hline Level of School & 2.07 & 1.64 & 5.20 & 1.17 & 5.49 & 3.90 & 11.80 \\
\hline Teaching Experience & 1.03 & .65 & .15 & 3.70 & .28 & .61 & .37 \\
\hline $\begin{array}{l}\text { Level of School } \\
\text { Teaching Experience }\end{array}$ & 1.47 & .94 & 5.28 & 1.23 & .99 & 2.93 & 1.51 \\
\hline Level of School * Gender & 1.66 & 1.13 & 1.33 & 19 & .30 & .54 & .14 \\
\hline T. Experience * Gender & .73 & .07 & .47 & .63 & .47 & 1.17 & 1.10 \\
\hline $\begin{array}{l}\text { Gender * Level of School } \\
\text { *Teaching Experience }\end{array}$ & 0.69 & 27 & .17 & .30 & .23 & .59 & .38 \\
\hline
\end{tabular}

After checking the significant results of MANOVA, univariate analyses were also interpreted. Before checking ANOVA results, Bonferroni correction was done by dividing alpha value to the number of dependent variables $(.05 / 6=.008)$. According to the results which were indicated in Table 5 , only gender had a significant effect on TK variable $F(1,182)=10.21, p<.05$. However, gender had no significant effect on PK, F $(1,182)=1.41, p>.05 ; C K, F(1,182)=0.35, p>.05 ; T C K, F(1,182)=.09$, $p>.05 ; P C K, F(1,182)=.09, p>.05 ; T C K, F(1,182)=2.26, p>.05$. Besides, teaching experience and level of school variables had no significant effect on all dependent variables.

\section{Conclusion and Discussion}

This study aimed to develop and validate a TPACK scale to be used in investigating mathematics teachers' knowledge levels in TPACK components, and investigated if mathematics teachers' TPACK levels differed in terms of gender, teaching experience and level of school with a particular focus on primary and secondary mathematics teaching.

The mathematics curricula accepted by the Ministry of National Education (MoNE) in Turkey require teachers to create appropriate learning environments using information and communication technologies for students that have different experiences, characteristics, and skills (MoNE, 2013). Therefore, this study was needed to measure mathematics teachers' TPACK.

The scale developed for this study was specifically designed for mathematics teachers who were serving in middle and high schools. Over the years, several instruments have been developed for measuring TPACK perceptions of pre-service teachers who are trained in Mathematics Teaching departments (Dikkartin-Ovez \& Akyuz, 2013; Zelkowski et al., 2013). This instrument is different from others in that it measures in-service mathematics teachers' perceptions of TPACK.

The finalized instrument represented a valid, reliable, 39-item with six-factor structure including TK, $\mathrm{PK}, \mathrm{CK}, \mathrm{TCK}, \mathrm{PCK}$ and TPACK. For the successful integration of technology into mathematics teaching, 
teachers first need to be comfortable with their own competencies. Thus, this scale may be used as an instrument to determine TPACK competence of mathematics teachers. In addition, this scale may be used as an assessment tool for teachers to self-assess their competence in TPACK.

The scale developed included six domains but lacked TPK. This result indicated that TPK domain remained difficult for mathematics teachers to separate and self-report. Also, in Zelkowski et al.'s (2013) study, in which a scale was developed for pre-service mathematics teachers, it was determined that the scale developed lacked not only TPK domain but also TCK and PCK domains.

The present study revealed that there were significant differences between gender and TK component. Male teachers perceived their TK significantly higher than female teachers. There are studies supporting these findings (Bulut, 2012; Erdogan \& Sahin, 2010; Luik, Taimalu \& Suviste, 2018; Solak \& Cakir, 2014). The reason for this result might not be related to mathematics training but it might have stemmed from the fact that male students are more interested in technology related issues than females, and females are more interested in language and social sciences related topics than males. On the other hand, different from the current study, many studies indicated nonsignificant results in terms of TPACK levels and gender (Acikgul \& Aslaner, 2015; Jang \& Tsai, 2013; Koh \& Sing, 2011; Mai \& Hamzah, 2016; Mutluoglu, 2012; Ozturk, 2013). In contrast, Altun (2013) found that female teachers' CK, PK, PCK and TCK scores were significantly higher than those of the male teachers. Similarly, Karaca (2015) found that female pre-service teachers studying at computer and instructional technologies education had higher TPACK levels than males.

Another finding obtained from this study was that the year of teaching experience had no significant effect on TPACK. However, there are varying results in terms of teaching experience and TPACK levels in the literature. While some studies found that more experienced elementary science and mathematics teachers' CK, PCK, TCK and overall TPACK were significantly higher than less experienced teachers (Altun, 2013; Jang \& Tsai, 2013), other studies found that teachers who had more teaching experience had less TK (Jordan, 2013; Lee \& Tsai, 2010; Mutluoglu (2012).

The last variable investigated in this study was the level school at which teachers were working and it was unearthed that mathematics teachers who teach at primary schools perceived TPACK domains higher than the teachers working at secondary schools but this difference was not statistically significant. Teachers who work at secondary schools perceived their TPACK lower. The reason for this finding might stem from the fact that courses related to teaching and learning including school experience were distributed evenly in the Elementary Mathematics Teaching Department curriculum than those in the Secondary Mathematics Teaching Department curriculum which includes teaching experience courses mostly in the last years of the curriculum. Similarly, in the study conducted by Saralar (2016), it was unearthed that TPACK level of pre-service teacher increased during school experience course. Although pre-service teachers' TPACK level slightly increased in terms of integrating technology to the curriculum and access of students to technology levels, a significant increase was found in pre-service teachers' teaching and learning with technology levels during the school experience course. Hence, secondary school mathematics teachers are supposed to be provided with quality in-service training activities that aim to enhance teachers' TPACK and make them more comfortable with their technology use competencies. In contrast, in the study of Erdogan and Sahin (2010), it was displayed that there was a significant difference according to level of schools. The level of TPACK of elementary mathematics teacher 
candidates was higher than that of secondary mathematics teacher candidates. However, Kagizmanli et al. (2013) did not find a significant difference according to the level of schools for TPACK constructs.

\section{Limitations and Recommendations}

All in all, this study contributed to the TPACK literature through the development of a valid and reliable instruments to examine mathematics teachers' understanding about the TPACK knowledge domains. This study has one important limitation which is the sample size. It included 202 mathematics teachers. Further research should be conducted by including a larger sample and mixed-methods research designs by qualitative data collection techniques like classroom observations, interviews and video analyses. Especially classroom observations should be conducted to investigate the correlation between teachers' levels of self-reflected TPACK and the actual TPACK levels which were demonstrated in their classroom applications.

In mathematics teacher training programs, great importance is attached to the development of CK but there are limited courses for pre-service teachers to be able improve TK, TPK and TPACK by blending the components of TPACK as stated by Kaya and Dag (2013). Hence, TPACK and its components should be discussed as complementary parts of mathematics education rather than independent parts in teacher training programs. As it was shown in Harvey and Caro's (2017) study, one group of pre-service teachers was explicitly taught the TPACK framework while the other group was not. Both groups were administered a pre/post TPACK assessment. The findings revealed positive results in explicitly using the TPACK framework in developing these skills in pre-service teachers. Besides, in order to ensure mathematics teaching; teachers should know the content, objective of the course, consider learning difficulties of pre-service teachers and use the most suitable technologies like dynamic mathematical software, Geogebra, interactive whiteboards, interactive student response systems by including constructivist teaching-learning methods and techniques such as cooperative learning, peer learning, computer based instruction, project based learning and evaluation methods such as portfolios, self-evaluation, peer-evaluation and concept maps.

Also, it is suggested that mathematics teachers might be provided with in-service training in terms of pedagogical and technological support to improve students' learning. As it was found in Loong and Herbert's (2018) study, which analyzed two primary teachers' degree of integration of digital technology in the mathematics classroom, it was unearthed that teachers' use of digital technology in the classroom was connected to their TPACK developmental stages of exploring and adapting in which one teacher approached the mathematical content through using a 'learning with ICT' approach and the other was a case of 'fitting ICT in' to existing pedagogies. Thus, teachers should move away from traditional instruction and go beyond one way teaching by just using chalk, blackboard, and problem solving. They should try to use technology and active teaching methods to show multiple representations of mathematical concepts and increase their understanding and involvement in mathematics. In many studies, pre-service teachers were found to have knowledge of pedagogy, content, and technology but they are in need of knowing how to use technology effectively and strategically in their teaching to create more opportunities for learning (Henriques \& Gutiérrez-Fallas, 2017). Therefore, teacher training programs should help pre-service teachers to 
integrate technology into instruction by establishing pedagogical connections between the affordances of technology and the teaching of mathematics to improve their TPACK levels.

It is suggested that besides in-service training, pre-service teachers should be provided with courses including the use of technology related to mathematics like computer algebra systems, dynamic mathematical software, Geogebra, interactive whiteboards, personal response systems. In this way, teachers can be ready to integrate technology into learning and teaching process to enhance their TPACK levels.

Finally, it may be recommended that researchers can use multiple instruments such as surveys, planning lessons, in-class observations, interviews or reflections to investigate deeply teachers' TPACK across different variables and reveal the reasons of the obtained results in detail.

\section{References}

Acikgul, K. \& Aslaner, R. (2015). Illkogretim matematik ogretmen adaylarinin TPAB guven algilarinin incelenmesi. Erzincan Universitesi Egitim Fakultesi Dergisi, 17(1), 118-152.

Altun, T. (2013). Examination of classroom teachers' technological pedagogical and content knowledge on the basis of their demographic profiles. Croatian Journal of Education, 15(2), 365-397.

Baran, E. \& Canbazoglu-Bilici, S. (2015). A review of the research on technological pedagogical content knowledge: The case of Turkey. Hacettepe University Journal of Education, 30(1), 15-32.

Bulut, A. (2012). Investigating perceptions of preservice mathematics teachers on their technological pedagogical content knowledge (TPACK) regarding geometry (Unpublished masters' thesis). Middle East Technical University, Ankara.

Canbazoglu-Bilici, S., Yamak, H., Kavak, N., \& Guzey, S. (2013). Technological pedagogical content knowledge self efficacy scale for preservice science teachers: Construction, validation and reliability. Eurasian Journal of Educational Research, 52, 37-60.

Cetin, I. \& Erdogan, A. (2018). Development, validity and reliability study of technological pedagogical content knowledge (TPACK) efficiency scale for mathematics teacher candidates. International Journal of Contemporary Educational Research, 5(1), 50-62.

Chai, C. S., Koh, J. H. L., \& Tsai, C. C. (2011). Exploring the factor structure of the constructs of technological, pedagogical, content knowledge (TPACK). The Asia-Pacific Education Researcher, 20(3), 595-603.

Creswell, J. W. (2012). Educational research: Planning, conducting, and evaluating quantitative and qualitative research. Boston: Pearson.

Dede, Y. \& Argun, Z. (2003). Matematik ogretiminde elektronik tablolarin kullanimi. Pamukkale University Faculty of Education Journal, 2(14), 113-131. 
Demir, S. \& Bozkurt, A. (2011). Primary mathematics teachers' views about their competencies concerning the integration of technology. Ilkogretim Online, 10(3), 850-860.

Dikkartin-Ovez, F. T. \& Akyuz, G. (2013). Ilkogretim matematik ogretmeni adaylarinin teknolojik pedagojik alan bilgisi yapilarinin modellenmesi. Education and Science, 38(170), 321-334.

Erdogan, A. \& Sahin, I. (2010). Relationship between math teacher candidates' technological pedagogical and content knowledge (TPACK) and achievement levels. Procedia-Social and Behavioral Sciences, 2(2), 2707-2711. DOI:10.1016/j.sbspro.2010.03.400

Feldt, R. C., Graham, M., \& Dew, D. (2011). Measuring adjustment to college: Construct validity of the student adaptation to college questionnaire. Measurement and Evaluation in Counseling and Development, 44(2), 92-104.

Field, A. (2009). Discovering statistics using SPSS (3 ${ }^{\text {rd }} E d$.). London: Sage.

Fraenkel, J. R. \& Wallen, N. E. (2009). How to design and evaluate research in education. Boston: McGraw-Hill.

Graham, C. R. (2011). Theoretical considerations for understanding technological pedagogical content knowledge (TPACK). Computers \& Education, 57(3), 1953-1960.

Groth, R., Spickler, D., Bergner, J., \& Bardzell, M. (2009). A qualitative approach to assessing technological pedagogical content knowledge. Contemporary Issues in Technology and Teacher Education, 9(4), 392-411.

Hair, J. F., Black, W., Babin, B., \& Anderson, R. E. (2010). Multivariate data analysis ( $7^{\text {th }}$ Ed.). New York: Pearson Prentice Hall.

Harvey, D.M. \& Caro, R. (2017). Building TPACK in preservice teachers through explicit course design. TechTrends, 61, 106-114.

Henriques, A. \& Gutiérrez-Fallas, L. F. (2017, March). Prospective mathematics teachers' beliefs and TPACK for teaching statistics. Proceedings of INTED2017 Conference (pp. 7193-7203). Valencia, Spain.

Jang, S. \& Chen, K. (2013). Development of an instrument to assess university students' perceptions of their science instructors' TPACK. Journal of Modern Education Review, 3(10), 771-783.

Jang, S. J. \& Tsai, M. F. (2013). Exploring the TPACK of Taiwanese secondary school science teachers using a new contextualized TPACK model. Australasian Journal of Educational Technology, 29(4), 566-580.

Jordan, K. (2013). The influence of gender on beginning teachers' perceptions of their technological pedagogical content knowledge (TPACK). Australian Educational Computing, 28(2), 1-21.

Kablan, Z., Baran, T., Isik, C., Kal, F. M., \& Hazer, O. (2013). PowerPoint ogretim materyalleri ile somut ogretim materyallerin ogrenme etkililigi acisindan karsilastirilmasi. Education and Science, 38(170), 206-222. 
Kagizmanlı, T. B., Tatar, E., \& Zengin, Y. (2013). Ogretmen adaylarinin matematik ogretiminde teknoloji kullanimina ilişkin algilarinin incelenmesi. Ahi Evran Universitesi Kirsehir Egitim Fakultesi Dergisi, 14(2), 349-370.

Karaca, F. (2015). An investigation of preservice teachers' technological pedagogical content knowledge based on a variety of characteristics. International Journal of Higher Education, 4(4), 128-136.

Kartal, B. \& Cinar, C. (2018). Examining pre-service mathematics teachers' beliefs of tpack during a method course and field experience. Malaysian Online Journal of Educational Technology, 6(3), 11-37.

Kaya, S. \& Dag, F. (2013). Sinif ogretmenlerine yonelik teknolojik pedagojik icerik bilgisi olceginin Turkceye uyarlanmasi. Educational Sciences: Theory \& Practice, 13(1), 291-306.

Khine, M.S., Ali, N., \& Afari, E. (2017). Exploring relationships among TPACK constructs and ICT achievement among trainee teachers. Education and Information Technologies, 22, 16051621. DOI: 10.1007/s10639-016-9507-8

Koehler, M. J. \& Mishra, P. (2005). What happens when teachers design educational technology? The development of technological pedagogical content knowledge. Journal of Educational Computing Research, 32(2), 131-152.

Koehler, M. J. \& Mishra, P. (2009). What is technological pedagogical content knowledge? Contemporary Issues in Technology and Teacher Education, 9(1), 60-70.

Koh, J. H. L. \& Sing, C. C. (2011). Modeling pre-service teachers' technological pedagogical content knowledge (TPACK) perceptions: The influence of demographic factors and TPACK constructs. In G. Williams, N. Brown, M. Pittard, B. Cleland (Eds.), Changing demands, changing directions: Proceedings of ASCILITE 2011 (pp.735-746). Hobart, Australia.

Kurt, G., Akyel, A., Kocoglu, Z., \& Mishra, P. (2014). TPACK in practice : A qualitative study on technology integrated lesson planning and implementation of Turkish pre-service teacher of English. ELT Research Journal, 3(3), 153-166.

Landry, G.A. (2010). Creating and validating an instrument to measure middle school mathematics teachers' technological pedagogical content knowledge (TPACK). (Unpublished doctoral dissertation). University of Tennessee, Knoxville. Retrieved on 13 January 2018 from http://trace.tennessee.edu/utk_graddiss/720/

Lee, M. H. \& Tsai, C. C. (2010). Exploring teachers' perceived self-efficacy and technological pedagogical content knowledge with respect to educational use of the World Wide Web. Instructional Science, 38(1), 1-21. DOI:10.1007/s11251-008-9075-4.

Loong, E. Y. K. \& Herbert, S. (2018). Primary school teachers' use of digital technology in mathematics: The complexities. Mathematics Education Research Journal, 30, 475-498.

Luik, P., Taimalu, M., \& Suviste, R. (2018). Perceptions of technological, pedagogical and content knowledge (TPACK) among pre-service teachers in Estonia. Education and Information Technologies, 23, 741-755. 
Mai, M. Y. \& Hamzah, M. (2016). Primary science teachers' perceptions of technological pedagogical and content knowledge (TPACK) in Malaysia. European Journal of Social Sciences Education and Research, 6(2), 167-179.

Mandaci-Sahin, S., Aydogan-Yenmez, A., Ozpinar, İ., \& Kogce, D. (2013). Ogretmen adaylarinin teknolojik pedagojik alan bilgisi modeline uygun bir hizmet oncesi egitim programinin bilesenlerine iliskin gorusleri. Hacettepe Universitesi Egitim Fakultesi Dergisi, Ozel Sayi (1), 271-286.

Mcgrath, J., Karabas, G., \& Willis, J. (2011). From TPACK concept to TPACK practice : An analysis of the suitability and usefulness of the concept as a guide in the real world of teacher development. International Journal of Technology in Teaching and Learning, 7(1), 1-23.

MoNE (2013). Ortaogretim matematik (9, 10, 11 ve 12. siniflar) dersi ogretim programi. Retrieved on 20 October 2017 from http://ttkb.meb.gov.tr/www/ogretimprogramlari/icerik/72

Mutluoglu, A. (2012). Ilkogretim matematik ogretmenlerinin ogretim stili tercihlerine gore teknolojik pedagojik alan bilgisi (TPAB) duzeylerinin incelenmesi (Unpublished master's thesis). Necmettin Erbakan University, Konya.

Ocak, M. A., Gokcearslan, S., \& Solmaz, E. (2014). Investigating Turkish pre-service teachers' perceptions of blogs: Implications for the FATIH project. Contemporary Educational Technology, 5(1), 22-38.

Ozturk, E. \& Horzum, M. B. (2011). Teknolojik pedagojik icerik bilgisi olceginin Turkceye uyarlamasi. Ahi Evran University Journal of Faculty of Education, 12(3), 255-278.

Ozturk, E. (2013). Sinif ogretmeni adaylarinin teknolojik pedagojik alan bilgilerinin bazi degiskenler acisindan degerlendirilmesi. Usak Universitesi Sosyal Bilimler Dergisi, 13, 223-238.

Pamuk, S., Ulken, A., \& Sener-Dilek, N. (2012). Ogretmen adaylarinin ogretimde teknoloji kullanim yeterliliklerinin teknolojik pedagojik icerik bilgisi kuramsal perspektifinden incelenmesi. Mustafa Kemal Universitesi Sosyal Bilimler Enstitusu Dergisi, 9(17), 415-438.

Pamuk, S., Ergun, M., Cakir, R., Yilmaz, H. B., \& Ayas, C. (2015). Exploring relationships among TPACK components and development of the TPACK instrument. Education and Information Technologies, 20, 241-263.

Patahuddin, S.M., Lowrie, T., \& Dalgarno, B. (2016). Analysing mathematics teachers' TPACK through observation of practice. Asia-Pacific Education Research, 25(5-6), 863-872. DOI: 10.1007/s40299-016-0305-2

Sancar-Tokmak, H., Incikabi, L., \& Ozgelen, S. (2013). An investigation of change in mathematics, science, and literacy education pre-service teachers' TPACK. The Asia Pacific Education Researcher, 22(4), 407-415. DOI: 10.1007/s40299-012-0040-2.

Saralar, I. (2016). A pre-service mathematics teacher's technological pedagogical content knowledge regarding different views of 3-D figures in geometry (Unpublished masters' thesis). Middle East Technical University, Ankara. 
Schmidt, D., Baran, E., Thompson, A. D., Mishra, P., Koehler, M. J., \& Shin, T. S. (2009). Technological pedagogical content knowledge (TPACK): The development and validation of an assessment instrument for preservice teachers. Journal of Research on Technology in Education, 42(2), 123-149. DOI:10.1007/978-1-60761-303-9

Semiz, K. \& Ince, M.L. (2012). Pre-service physical education teachers' technological pedagogical content knowledge, technology integration self-efficacy and instructional technology outcome expectations. Australasian Journal of Educational Technology, 28(7), 1248-1265.

Shulman, L. S. (1986). Those who understand: Knowledge growth in teaching. Educational Researcher, 15(2), 4-14.

Shulman, L. S. (1987). Knowledge and teaching: Foundations of the new reform. Harvard Educational Review, 57(1), 1-22.

Solak, E. \& Cakir, R. (2014). Examining pre-service EFL teachers' TPACK competencies in Turkey. Journal of Educators Online, 11(2), 1-22.

Stevens, J. P. (1992). Applied multivariate statistics for the social sciences (2 ${ }^{\text {nd }}$ Ed.). Hillsdale, NJ: Erlbaum.

Tabachnick, B. G. \& Fidell, L. S. (2007). Using multivariate statistics. Boston: Pearson Education.

Zelkowski, J., Gleason, J., Cox, D. C., \& Bismarck, S. (2013). Developing and validating a reliable TPACK instrument for secondary mathematics preservice teachers. Journal of Research on Technology in Education, 46(2), 173-206. DOI: 10.1080/15391523.2013.10782618

Zengin-Unal, O. (2015). Investigating the use of mobile-based vocabulary notebooks on students' vocabulary achievement in English language learning (Unpublished master's thesis). Middle East Technical University, Ankara.

Correspondence: Fatma Ozudogru, Assistant Professor, Department of Curriculum and Instruction, Faculty of Education, Usak University, Usak, Turkey 